\title{
Immunochemical Analysis of Streptococcus bovis, Strain s19, Cell Walls
}

\author{
By J. A. KANE AND W. W. KARAKAWA \\ Department of Microbiology, Pennsylvania State University, \\ University Park, Pennsylvania 16802, U.S.A.
}

(Accepted for publication 6 January 1969)

SUMMARY

Two antigens, a glucose-rich capsular polymer and a cell wall carbohydrate consisting of $\mathrm{N}$-acetylglucosamine, glucose and rhamnose, were isolated from Streptococcus bovis, strain S 19. N-acetylglucosamine and a haptenic fraction rich in glucosamine inhibited approximately 56 and $63 \%$ of the quantitative precipitin reaction between the $\mathrm{S}$ I 9 cell wall carbohydrate and its homologous antiserum, respectively. A cross-reactivity between a preparation of azo-protein, which consisted of terminal $\beta$ - $N$-acetylglucosaminide residues, and S 19 antiserum substantiated the fact that $N$-acetylglycosamine is one of the major antigenic determinants of the S I9 cell-wall carbohydrate.

Haptenic inhibition studies have not revealed any structural feature of the antigenic determinant of the glucose-rich capsular polymer.

\section{INTRODUCTION}

Medrek \& Barnes (I962) have shown that Streptococcus bovis, a member of the group D streptococci, can be separated into at least $\mathrm{I} 2$ serological types on the basis of precipitin reactions. The type-specificity of 75 strains, in most instances, was attributed to a capsular-like material. However, in view of the fact that the immunochemical basis for the antigenic specificity of these type-specific substances has not been elucidated, it is possible that the observed type-specific reactions may also be dependent upon components of the cell wall other than the capsular material.

Elliott (1960) reported the isolation of type-specific carbohydrates consisting of glucosamine, rhamnose and glucose from four serological types of group D streptococci. These type-specific carbohydrates were shown to be components of the cell wall and, therefore, were considered to be the structural counterpart of the group-specific carbohydrates of groups A, B, C, and G hemolytic streptococci.

This report describes the isolation, purification and chemical properties of the typespecific carbohydrates of Streptococcus bovis (Medreks strain S I 9 type I0), and defines in immunochemical terms the basis for the antigenic specificity of the cell-wall carbohydrate.

\section{METHODS}

Streptococcal strains. Streptococcus bovis strains S I9 (Medrek's type ro), C IoI (type 5) and C 33 (type 2) were obtained from Dr R. C. Lancefield of the Rockefeller University. Strains TMC 3 (type I), TMC 36 (type 3), TMC 48 (type 4) and TMC IO6 (type 6) 
were kindly supplied by Dr E. M. Barnes, Agricultural Research Council, Food Research Institute, Norwich, England.

Preparation of cell walls. Cell walls were prepared from Streptococcus bovis according to the method of Bleiweis, Karakawa \& Krause (1964).

Analytical methods. Amino acids, glucosamine and muramic acid were determined by the method of Moore, Spackman \& Stein (I958) as described by Karakawa \& Krause (1966) and employed the Beckman, Spinco model I20 C, amino acid analyser. Total hexosamine was determined by the method described by Rondle \& Morgan (1955). The method of Dische \& Shettles (1948) was used for the quantitation of rhamnose. Glucose was determined by the method described by Curtis \& Krause (1964) which employed the glucostat reagent (Worthington Biochemical Corporation, Freehold, New Jersey).

Sephadex gel filtration. Partially purified cell-wall carbohydrates and capsular material were subjected to Sephadex gel filtration according to the method described by Karakawa \& Krause (1966).

Ion exchange chromatography. Crude capsular carbohydrate was purified on diethylaminoethylcellulose (DEAE-cellulose, Gallard-Schlesinger Chemical Manufacturing Corp., N.Y., 0.68 m-equiv./g.) according to the method described by Young (I966). The column was eluted with $0.02 \mathrm{M}-\left(\mathrm{NH}_{4}\right)_{2} \mathrm{CO}_{3}$ buffer at $\mathrm{pH} 8.6$ and the absorbance of the $5 \mathrm{ml}$. fractions was read at $220 \mathrm{~m} \mu$ in a Beckman DU-2 spectrophotometer.

Streptococcal vaccine. The vaccine was prepared from Streptococcus bovis, strain S I9, according to the method described by McCarty \& Lancefield (I955). The bacteria were grown in $500 \mathrm{ml}$. of Todd-Hewitt broth at $37^{\circ}$ and collected by centrifugation. The bacterial sediment was resuspended in $20 \mathrm{ml}$. of $0.2 \%$ formalized saline and stored at $4^{\circ}$.

Detection of antibodies. Group D type-specific antibodies were detected by the capillary precipitin test employed by Swift, Wilson \& Lancefield (I943).

Quantitative precipitin analyses were performed according to the method of McCarty (1952).

Zone electrophoresis. Zone electrophoresis of serum proteins employed a Beckman model R-IO I Microzone cell according to the method described by Osterland, Miller, Karakawa \& Krause (1966).

\section{RESULTS}

Previous studies have shown that Streptococcus bovis can be separated into at least I 2 serological types on the basis of type-specific carbohydrates (Medrek \& Barnes, I962). These type-specific reactions were considered, in most instances, to be due to a capsular material. However, definitive data on the isolation and analysis of these substances are not available and, therefore, the immunochemical nature of the typespecific substances has not be established. The following studies were designed in an attempt to determine the immunochemical basis for the antigenic specificity of $S$. bovis strain S I9, type Io.

Preparaton of specific carbohydrates. Specific carbohydrates were extracted from the cell walls of Streptococcus bovis strains S 19, C IoI, C 33, TMC 3, TMC 36, TMC 48 and TMC IO6 by the hot formamide method of Fuller (1938) as modified by Krause \& McCarty (196I). In this procedure the cell walls, which are composed primarily of a 
carbohydrate fraction and a rigid mucopeptide matrix, were treated with formamide at $170^{\circ}$ for $15 \mathrm{~min}$. The proteins were precipitated from the extract by the addition of acid ethanol; after centrifugation the crude polysaccharide was precipitated with 5 vol. of acetone. The polysaccharide was then subjected to gel filtration on a Sephadex G-I00 column ( $90 \times$ I 5 mm.). The chemical composition of $S$. bovis (strain S 19) cell walls, the carbohydrate extracted with hot formamide and the mucopeptide residue is shown in Table $I$. As in the case of the group D streptococci previously examined (Elliott, I960), the bulk of the rhamnose is associated with the soluble carbohydrate; whereas the mucopeptide residue is essentially devoid of this sugar. The other sugars associated with the carbohydrate are glucosamine and glucose. It should be noted that the concentration of threonine is noticeably high and suggests that this amino acid might be a structural component of the $S$. bovis mucopeptide. This observation was a consistent finding in all seven strains tested. Work is now in progress to determine the value of threonine as a taxonomic tool in the identification of $S$. bovis.

Table I. Chemical composition of Streptococcus bovis, strain SI9, cell walls and the soluble carbohydrate $(\mathrm{CHO})$ and the insoluble residue after hot formamide extraction

$\begin{array}{lccc}\text { Constituent } & \begin{array}{c}\text { Cell wall } \\ (\mu \mathrm{mole} / \mathrm{mg} .)\end{array} & \begin{array}{c}\text { Extracted } \\ \text { CHO } \\ (\mu \mathrm{mole} / \mathrm{mg} .)\end{array} & \begin{array}{c}\text { Formamide } \\ \text { residue } \\ (\mu \mathrm{mole} / \mathrm{mg} .)\end{array} \\ \begin{array}{lcc}\text { Glucosamine } \\ \text { Rhamnose }\end{array} & 0.4 \mathrm{I} & 0.55 & 0.39 \\ \text { Glucose } & 0.46 & \mathrm{I} .4 \mathrm{I} & <0.0 \mathrm{I} \\ \text { Muramic acid } & 0.70 & \mathrm{I} .55 & <0.0 \mathrm{I} \\ \text { Alanine } & 0.25 & <0.0 \mathrm{I} & 0.4 \mathrm{I} \\ \text { Glutamic acid } & 0.79 & <0.01 & \mathrm{I} \cdot \mathrm{I} 5 \\ \text { Lysine } & 0.44 & <0.0 \mathrm{I} & 0.52 \\ \text { Glycine } & 0.33 & <0.01 & 0.4 \mathrm{I} \\ \text { Threonine } & 0.13 & <0.0 \mathrm{I} & 0.04 \\ \text { Ammonia } & 0.18 & <0.0 \mathrm{I} & 0.24 \\ & 0.33 & 0.16 & 0.24\end{array}$

Table 2. Chemical composition of formamide-extracted cell-wall carbohydrate of Streptococcus bovis

\begin{tabular}{lccc} 
& \multicolumn{3}{c}{} \\
\cline { 2 - 4 } $\begin{array}{c}\text { S I9 } \\
\text { Constituent }\end{array}$ & $\begin{array}{c}\text { C IOI } \\
(\mu \mathrm{mole} / \mathrm{mg} .)\end{array}$ & $\begin{array}{c}\mathrm{C} 33 \\
(\mu \mathrm{mole} / \mathrm{mg} .)\end{array}$ \\
Glucose & $\mathrm{I} \cdot 55$ & $\mathrm{I} \cdot \mathrm{IO}$ & $\mathrm{I} \cdot \mathrm{I} 5$ \\
Glucosamine & 0.55 & 0.26 & 0.94 \\
Rhamnose & $\mathrm{I} \cdot 4 \mathrm{I}$ & $\mathrm{I} \cdot 97$ & 0.98
\end{tabular}

Chemical analysis of the cell-wall carbohydrates isolated from strains C IOI and C 33 revealed chemical constituents similar to strain si9. These results are shown in Table 2. Note that glucose, rhamnose and glucosamine are significant components of the cell-wall carbohydrates of all three strains; however, there is considerable variation in their relative concentrations. Strain C 33 carbohydrate contains a higher concentration of glucosamine than do strains S I9 and C IOI. Rhamnose, on the other hand, is more abundant in strain $\mathrm{C}$ IOI than in the other strains. 
Isolation of the capsular material from strain S 19. Medrek \& Barnes (1962) suggested that the type-specific reaction of I I of the I2 types of Streptococcus bovis was dependent upon a capsular-like material. In the present studies, washed S. bovis (strain S I9), grown in beef-heart infusion broth containing 3\% sucrose, were suspended in saline and homogenized at low speed in a Waring blendor for $5 \mathrm{~min}$. The cocci were removed by centrifugation; and the clear supernatant, which contained the capsular material, was subjected to DEAE-cellulose chromatography and Sephadex G-75 gel-filtration as described in Methods. The results of the DEAE-cellulose chromatography of the crude capsular material are shown in Fig. I. It should be noted that only a single major fraction was eluted from the DEAE-cellulose column. This substance after further purification by gel filtration, consisted of $3.95 \mu$ mole glucose $/ \mathrm{mg}$., $0.09 \mu$ mole glucosamine/mg., and $0.01 \mu$ mole rhamnose $/ \mathrm{mg}$. Only minimal amounts

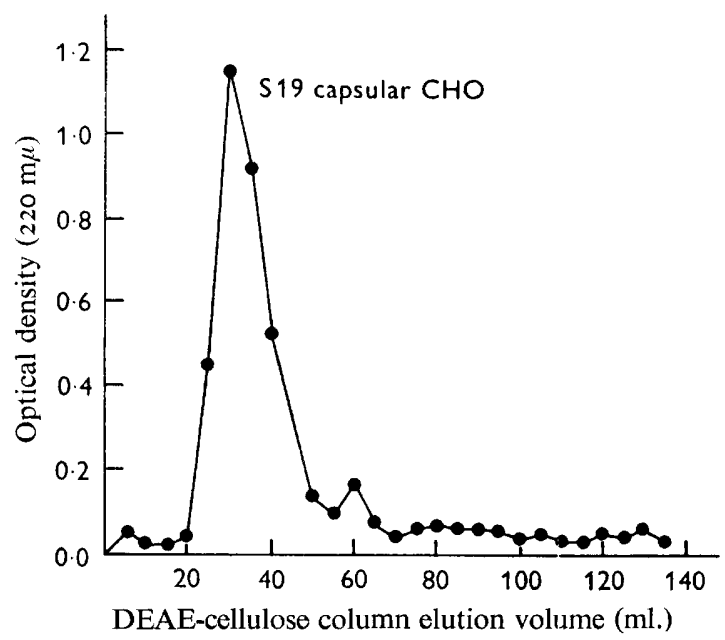

Fig. I

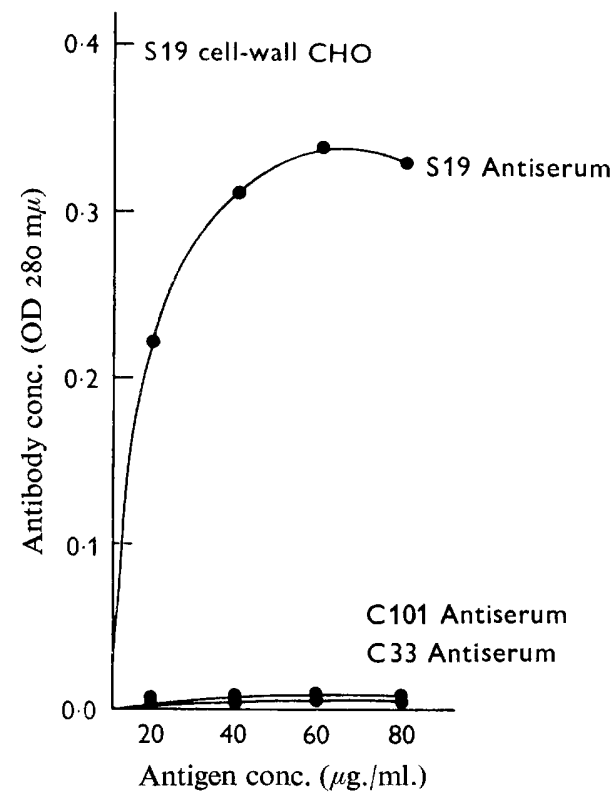

Fig. 2

Fig. I. DEAE-cellulose column chromatography of the capsular material (CHO) of Streptococcus bovis, strain si 9 . Column dimensions: $300 \times 30 \mathrm{~mm}$. Buffer: $0.02 \mathrm{M}-\left(\mathrm{NH}_{4}\right)_{2} \mathrm{CO}_{3}$, $\mathrm{pH} 8.4$ at $4^{\circ}$.

Fig. 2. Quantitative precipitin reaction between the purified cell-wall carbohydrate of Streptococcus bosi (strain S 19) and anti-S 19, C IOI and C 33 sera.

of phosphorus were detected, which suggest that the glucose polymer was not a teichoic acid. An abundance of the glucose-rich polymer was also isolated from the growth medium by the method described by Michel \& Krause (1967). These results and those presented in Table 2 clearly suggest that $S$. bovis, strain S 19, contains two chemically distinct carbohydrates: a glucose-rich polymer and a cell-wall carbohydrate.

Absorption of serum with Streptococcus bovis, strains S 19, C IOI, and C 33, cell walls. The following serological studies were designed to establish the fact that the antibodies present in the $\mathrm{S}$ I 9 antiserum are elicited by type-specific cell-wall carbohydrates and are 
$\gamma$-globulins. Strain S I9 antiserum was absorbed with capsular-free cell walls of strains S 19, C IOI, and C 33 (I mg. $/ \mathrm{ml}$ ) at $37^{\circ}$ for $30 \mathrm{~min}$. Following absorption with s 19 cell walls, no cell-wall carbohydrate antibodies were detected in the absorbed $s$ I 9 antiserum by the capillary precipitin test; whereas, antiserum S 19 absorbed with C IOI and $\mathrm{C} 33$ cell walls gave strong precipitin reactions with S I9 cell-wall carbohydrate. When antibodies recovered from the S I9 cell wall/antibody complex by the acid dissociation technique of Osterland et al. (1966) were subjected to zone electrophoresis, the electrophoretic patterns revealed a single band with a mobility similar to that of the $\gamma$-globulin peak of the unabsorbed $S$ I9 antiserum. This isolated antibody preparation was identified as IgG-globulin by means of immunoelectrophoresis.

Antigenic properties of carbohydrates extracted from Streptococcus bovis, strain S I9. The results of the quantitative precipitin tests between $S$ I 9 cell-wall carbohydrate and antisera S I9, C IOI and $\mathrm{C} 33$ are shown in Fig. 2. The s I9 cell-wall carbohydrate gave a significant quantitative precipitin reaction with its homologous antiserum; whereas the reactions with the heterologous antisera were less reactive in this respect. Quantitative precipitin tests between the carbohydrates of strains TMC 3, TMC 36 , TMC 48 and TMC IO6 and S I9 antiserum were negative. These results clearly substantiate the fact that the reaction between strain S 19 cell-wall carbohydrate and its homologous antiserum is type-specific.

Table 3. Chemical composition of partially acid-hydrolysed cell-wall carbohydrate of Streptococcus bovis, strain $S 19$

\begin{tabular}{lcccc} 
& \multicolumn{4}{c}{ Carbohydrate $(\mu \mathrm{mole} / \mathrm{mg})}$. \\
\cline { 2 - 4 } \multicolumn{1}{c}{ Constituent } & Untreated & Mole ratio & Treated & Mole ratio \\
Glucosamine & 0.55 & $\mathrm{I} \cdot 0$ & $0 \cdot 32$ & $\mathrm{I} \cdot 0$ \\
Glucose & $\mathrm{I} \cdot 55$ & $2 \cdot 8$ & $\mathrm{I} \cdot 63$ & $5 \cdot \mathrm{I}$ \\
Rhamnose & $\mathrm{I} \cdot 4 \mathrm{I}$ & $2 \cdot 5$ & $\mathrm{I} \cdot 54$ & $4 \cdot 8$
\end{tabular}

The glucose-rich capsular material isolated from a culture of strain S I9 gave a very weak precipitin reaction with homologous antiserum. Work is now in progress to obtain precipitating antibodies against this glucose polymer from swine and horses.

Characterization of the type-specific determinant of strain $S 19$ cell wall carbohydrate. Results showed that the cell-wall carbohydrate of various strains of Streptococcus bovis possess similar chemical constituents but are immunologically distinct antigens. Theoretically, glucose, rhamnose or glucosamine could contribute to the antigenic specificity of the S 19 carbohydrate. In an attempt to determine the immunochemical basis for this antigenic specificity, purified S 19 carbohydrate was partially hydrolysed with $\mathrm{N} \mathrm{HCl}$ for $\mathrm{I} 5 \mathrm{~min}$. at $100^{\circ}$. The treated carbohydrate was subjected to Sephadex G-75 gel filtration and lyophilized. The results of the chemical analysis of this acidtreated carbohydrate are shown in Table 3. The treated carbohydrate contained less glucosamine than the untreated carbohydrate. Further, the acid-treated carbohydrate, when employed in a quantitative precipitin test, gave a markedly weaker reaction than the untreated carbohydrate. These results are depicted in Fig. 3. Note that the quantitative precipitin reaction between the treated carbohydrate and antiserum S I9 was more than $50 \%$ less than the precipitin reaction between the untreated carbohydrate and antiserum s 19. 
Monosaccharides and haptenic inhibitors were used in the quantitative precipitin inhibition studies between S I9 carbohydrate and S I 9 antiserum to test the view that glucosamine is the major antigenic determinant of the S 19 cell-wall carbohydrate. Among the inhibitors employed in these studies was a haptenic fraction consisting of glucosamine, glucose and rhamnose in a mole ratio of $1 \cdot 0: 0.5: 0 \cdot \mathrm{I}$ which was isolated from an acid-hydrolysate of the s 19 carbohydrate as described by Michel \& Willers (1964). The results of the quantitative precipitin inhibition studies are shown in Fig. 4. As depicted in this figure, $63 \%$ of the quantitative precipitin reaction between the $\mathrm{S} 19$ carbohydrate and its homologous antiserum was inhibited by the glucosamine-rich hapten. Further, $N$-acetylglucosamine inhibited approximately $56 \%$ of this quantitative precipitin reaction at a concentration of $10 \mathrm{mg} . / \mathrm{ml}$; whereas glucose and rhamnose were less reactive at the same concentration.

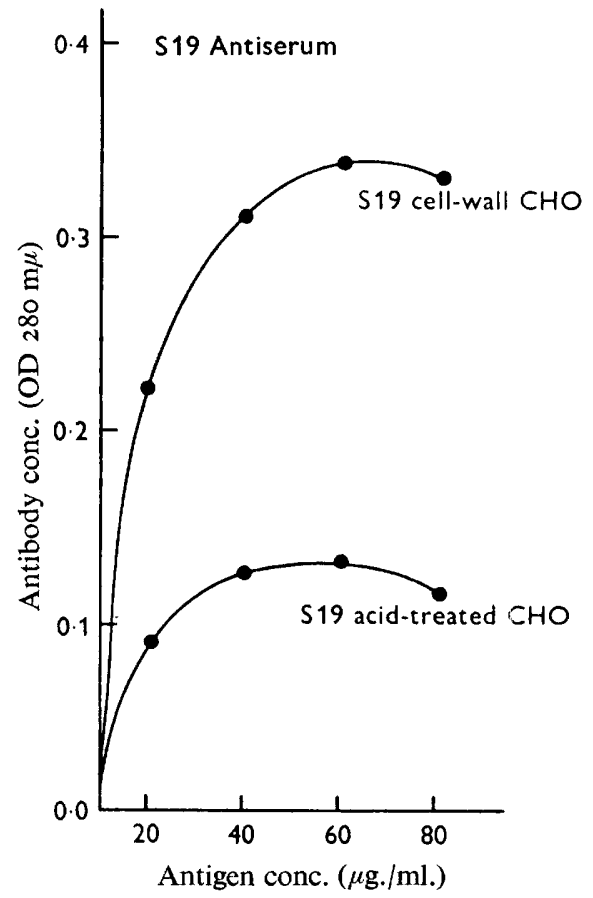

Fig. 3

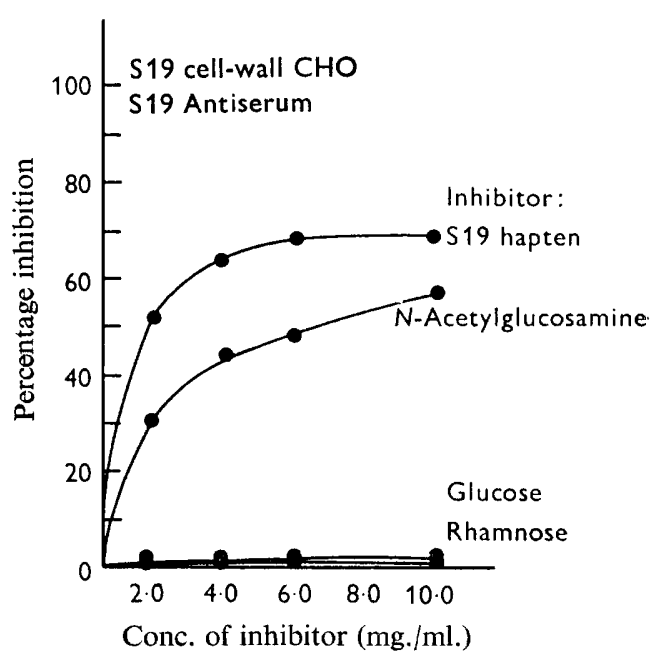

Fig. 4

Fig. 3. Quantitative precipitin reaction between the purified s ig cell-wall carbohydrate, purified $s \mathbf{1} 9$ acid-treated cell-wall carbohydrate and $s$ i 9 antiserum.

Fig. 4. Inhibition of the quantitative precipitin reaction between $\mathrm{s} 19$ carbohydrate and S 19 antiserum with monosaccharides and a glucosamine-rich haptenic fraction.

Further evidence to support the view that $\mathrm{N}$-acetylglucosamine is the immunodominant determinant of the S I9 carbohydrate was obtained from studies on the cross-reactivity between S I9 antiserum and ovalbumin-azo-phenyl- $\beta$ - $N$-acetylglucosamine. This azoprotein was kindly supplied by Dr M. McCarty, Rockefeller University. In these studies it was shown that the azoprotein cross reacted with horse antiserum S I9 and this precipitin reaction was specifically inhibited by 
$N$-acetylglucosamine at a concentration of $10 \mathrm{mg} . / \mathrm{ml}$. These results suggest that $\beta-N$-acetylglucosamine could be the immunodominant determinant of the $\mathrm{s} 19$ cellwall carbohydrate.

\section{DISCUSSION}

Evidence has been presented to indicate that strain S 19 contains at least two distinct carbohydrates: a glucose-rich polymer and a cell-wall carbohydrate consisting of $N$-acetylglucosamine, rhamnose and glucose. The capsular carbohydrate was shown to consist of glucose units with minimal concentrations of rhamnose and $\mathrm{N}$-acetylglucosamine. This finding is consistent with the observations of other investigators (Duguid, I95I; Dain, Seely \& Neal, 1956; Bailey \& Oxford, 1958). Bailey \& Oxford (1958), for example, consistently observed a dextran-like polysaccharide in certain strains of Streptococcus bovis which were grown in sucrose-enriched media. Haptenic inhibition studies, employing glucose, maltose, cellobiose and gentiobiose, have not revealed any of the structural features of the antigenic determinant of the capsular material.

The cell-wall carbohydrate, which is a structural analogue of the group-specific antigens of most haemolytic streptococci, was successfully isolated from a hot formamide extract of Streptococcus bovis. Purification was achieved by DEAE-cellulose chromatography and gel filtration. Quantitative precipitin inhibition studies, employing haptenic fractions isolated from partial acid hydrolysates of $\mathrm{S}$ I 9 carbohydrate, indicated that $\mathrm{N}$-acetylglucosamine comprised a portion of the antigenic determinant of the S I 9 carbohydrate.

McCarty (1956) has shown that terminal $N$-acetylglucosaminide residues are the major antigenic determinants of the group-specific carbohydrate of group A haemolytic streptococci. A cross-reaction between the group A and S I9 carbohydrates was observed in this study and suggests that $N$-acetylglucosamine, a common feature of both carbohydrates, could possibly be responsible for this cross-reactivity.

The existence of two major carbohydrate antigens in the cell walls is not uncommon in streptococci, Michel \& Krause (1967) isolated two antigens, a group-specific and a type-specific carbohydrate, from a hot formamide extract of group F streptococci. The type-specific antigen was composed of rhamnose, glucose, galactose and galactosamine; whereas the group-specific antigen was composed of rhamnose, glucose and galactosamine. Unlike Streptococcus bovis, strain s 19, both antigens were components of the cell walls. Group B streptococci also contain two carbohydrate antigens: a type-specific capsular material and a group-specific cell-wall carbohydrate (Lancefield, 1934).

The work reported here supports the view that Streptococcus bovis can be separated into distinct serological types (Medrek \& Barnes, 1962). Eventually, with greater knowledge of the immunochemistry of the carbohydrates associated with $S$. bovis, it seems feasible to assume that a useful system for the classification of these streptococci may be obtained, which will compare favourably with that employed for the haemolytic streptococci.

The authors wish to thank Dr R. C. Lancefield, Rockefeller University, for her interest in and criticism of this work. This work was supported by National Institute of Health Grant no. A I 080 I 5. 


\section{REFERENCES}

Bailey, R. W. \& Oxford, A. E. (1958). A quantitative study of the production of dextran from sucrose by rumen strains of Streptococcus bovis. J. gen. Microbiol. 19, 130.

Bleiweis, A. S., KarakaWa, W. W. \& Krause, R. M. (I964). Improved technique for the preparation of streptococcal cell walls. J. Bact. 88, I 198.

Curtis, S. N. \& Krause, R. M. (1964). Immunochemical studies on the specific carbohydrate of group G streptococci. J. exp. Med. r19, 997.

Dain, J. A., Seely, H. W. \& Neal, A. L. (1956). The effect of carbon dioxide on polysaccharide production by Streptococcus bovis. J. Bact. 72, 209.

Dische, A. \& SheTrles, L. B. (1948). A specific color reaction of methylpentoses and a spectrophotometric micromethod for their determination. J. biol. Chem. 175, 595.

Duguid, J. P. (I95I). The demonstration of bacterial capsules and slime. J. Path. Bact. 63, 673.

Elliott, S. D. (1960). Type and group polysaccharide of group D streptococci. J. exp. Med. III, 621.

Fuller, A. T. (1938). Formamide method for the extraction of polysaccharides from haemolytic streptococci. Br. J. exp. Path. 19, I 30.

Karakawa, W. W. \& Krause, R. M. (1966). Studies on the immunochemistry of streptococcal mucopeptide. J. exp. Med. 124, 155 .

Krause, R. M. \& MCCARTY, M. (196I). Studies on the chemical structure of the streptococcal cell wall. I. The identification of a mucopeptide in the cell walls of group A and A-variant streptococci. J. exp. Med. 114, 127.

LANCEFIELD, R. C. (1934). A serological differentiation of specific types of bovine haemolytic streptococci (group G). J. exp. Med. 59, $44 \mathrm{I}$.

MCCARTY, M. (1952). The lysis of group A haemolytic streptococci by extracellular enzymes of Streptomyces albus. II. Nature of the cellular substrate attacked by the lytic enzymes. J. exp. Med. 96, 569.

MCCARTY, M. (1956). Variation in the group specific carbohydrate of group A streptococci. II. Studies on the chemical basis for serological specificity of the carbohydrates. J. exp. Med. ro4, 629.

MCCARTY, M. \& LANCEFIELD, R. C. (I955). Variation in the group specific carbohydrate of group A streptococci. I. Immunochemical studies on the carbohydrate of variant strains. J. exp. Med. IO2, II.

Medrek, T. F. \& Barnes, E. M. (I962). The physiological and serological properties of Streptococcus bovis and related organisms isolated from cattle and sheep. J. appl. Bact. 25, I69.

Michel, M. \& Krause, R. M. (1967). Inmunochemical studies on the group and type antigens of group $\mathrm{F}$ streptococci and the identification of a group-like carbohydrate in a type II strain with an undesignated group antigen. J. $\epsilon x p$. Med. 125, 1075.

Michel, M. \& Willers, J. M. N. (1964). Immunochemistry of group F streptococci; isolation of group-specific oligosaccharides. J. gen. Microbiol. 37, 381 .

Moore, S., Spackman, D. H. \& Stein, W. H. (1958). Chromatography of amino acids on sulfonated polystyrene resins. Analyt. Chem. 30, I 185 .

Osterland, C. K., Miller, E. J., Karakawa, W. W. \& Krause, R. M. (1966). Characteristics of streptococcal group specific antibody isolated from hyperimmune rabbits. J. exp. Med. 123, 599.

Rondle, C. J. \& Morgan, W. T. J. (1955). The determination of glucosamine and galactosamine. Biochem. J. 6r, 586.

Swift, H. F., Wilson, A. T. \& Lancefifldd, R. C. (1943). Typing group A hemolytic streptococci by $\mathrm{M}$ precipitation reactions in capillary pipettes. J. exp. Med. $78,127$.

Young, F. E. (I966). Fractionation and partial characterization of the products of autolysis of cell walls of Bacillus subtilis. J. Bact. 92, 839 . 